\title{
Identifikasi Keluhan Kesehatan Mahasiswa Selama Perkuliahan Daring pada Masa Pandemic Covid19
}

\author{
Mohammad Sobirin \\ Program Studi Teknologi Industri, Institut Teknologi dan Sains Nahdlatul Ulama Pekalongan, \\ Jl. Karangdowo No.9, Kemoren, Karangdowo, Kec. Kedungwuni, Pekalongan, Jawa Tengah 51173 \\ Email: ir.mohammad.sobirin@gmail.com
}

DOI: 10.20961/performa.19.1.42583

\begin{abstract}
Abstrak
Mahasiswa merupakan faktor utama yang menentukan kegiatan perkuliahan berjalan dengan benar. Proses belajar yang lama menjadikan mahasiswa mengalami banyak keluahan. Dengan adanya kuliah daring akibat dari pandemic Covid19 ini, memungkinkan ketidaknyamanan mahasiswa pada saat perkuliahan semakin meningkat. Pada penelitian ini, dilakukan sebuah identitifikasi terkait keluhan kesehatan yang terjadi pada mahasiswa selama perkuliahan menggunakan metode daring.Metode penelitian adalah menggunakan metode descriptive dari perhitungan statistic dan penyebaran kuisioner NBM (Nordic Body Map). Pengambilan data dilakukan terhadap 30 mahasiswa mahasiswa di Institut Teknologi dan Sains Nahdlatul Ulama Pekalongan. Hasil analisis menunjukkan bahwa terjadi keluhan kesehatan berupa rasa sakit sementara, jangkat pannjang, dan permanen. Titik tubuh yang paling banyak terasa sakit adalah terletak pada area tangan (Bahu, lengan atas, lengan bawah, dan pergelangan), dan batang tubuh (leher, punggung, pinggul, pinggang dan pantat). Berdasarkan hasil ini dibutuhkan solusi berupa postur tubuh yang baik saat kerja, dan penggunaan perangkat kerja dan media pendung yang sesuai.
\end{abstract}

Kata kunci: Mahasiswa, Keluhan, Perkulihan, Daring, Postur.

\begin{abstract}
Students are the main factor that determines lecture activities run properly. The long learning process makes students experience many difficulties. With the online lecture as a result of the Covid19 pandemic, it is possible for student discomfort during lectures to increase. In this study, an identification was made related to health complaints that occur in students during lectures using the online method. The research method is to use descriptive methods from statistical calculations and the NBM (Nordic Body Map) questionnaire. Data collection was carried out on 30 students at the Institut Teknologi dan Sains Nahdlatul Ulama Pekalongan. The results of the analysis showed that health complaints occurred in the form of temporary pain, longevity, and permanence. The most painful body points are located in the area of the hands (shoulders, upper arms, forearms, and wrists), and the trunk (neck, back, hips, waist and buttocks). Based on these results a solution is needed in the form of good posture at work, and the use of work tools and appropriate supporting media.
\end{abstract}

Keywords: Students, Complaints, Lectures, Posture, Covid19..

\section{Pendahuluan}

Pada bulan Desember 2019 menjadi awal dari ditemukannya virus Corana19 (Coronavirus disease 2019) (Sukamana et al., 2020; Kar et al., 2020). Hingga bulan Juli 2020, korban yang berjatuhan di Indonesia sudah mencapai lebih dari 50.000 jiwa. Selain itu, pandemic ini juga berdampak pada banyak sektor yang menimbulkan kerugian yang tidak kecil. Salah satu sektor yang mengalami dampak langsung dari pandemic ini adalah pada bidang pendidikan. Sektor pendidikan sendiri terbagi kedalam banyak jenjang, mulai dari sekolah dasar hingga perguruan tinggi. Semua jenjang pendidikan tersebut oleh pemerintah Indonesia mulai ditutup sementara mulai pada bulan Maret 2020 hingga batas waktu yang belum ditentukan. Khususnya untuk jenjang perguruan tinggi, dampak yang paling nyata adalah kegiatan perkuliahan yang tidak dapat berjalan lancar sebagaimana mestinya. Kegiatan perkuliahan dilakukan secara daring, dengan ketentuan yang telah diatur oleh masing-masing pengelola perguruan tinggi (Minghat et al., 2020).

Mahasiswa merupakan faktor utama yang menentukan kegiatan perkuliahan berjalan dengan benar. Proses belajar yang lama antara 1 hingga 3 jam menjadikan mahasiswa mengalami banyak keluahan mulai dari stress kerja, bagian tubuh tertentu sakit, tidak fokus, dll. Kondisi ini menjadikan tantangan tersendiri bagi tenaga pengajar pada umumnya untuk dapat menciptakan suasana perkuliahan yang menarik, tidak membosankan, dan nyaman (Ng et al., 2016; Wajdi et al., 2020). Selain itu, sarana dan prasaran juga menjadi pendukung utama terhadap hal tersebut. Dengan adanya kuliah daring akibat dari pandemic Covid19 ini, memungkinkan ketidaknyamanan mahasiswa pada saat perkuliahan semakin meningkat. Oleh karena itu, berdasarkan permasalahan-permasalahan diatas menjadikan dibutuhkannya penelitian untuk dapat 
menanggulangi berbagai permasalahan yang mungkin dan sudah terjadi (Adams et al., 2015; Manghisi et al., 2017).

Pada penelitian ini, dilakukan sebuah identitifikasi terkait keluhan-keluahan yang terjadi pada mahasiswa selama melakukan perkuliahan menggunakan metode daring. Fokus penelitian adalah pada keluhan kesehatan pada mahasiswa sendiri. Metode penelitian adalah menggunakan metode descriptive dari perhitungan statistic dan penyebaran kuisioner NBM (Nordic Body Map). Metode Deskriptive digunakan untuk mengidentifikasi data-data dasar terkatait demograpi mahasiswa, yang kemudian diolah untuk menjadi suatu informasi baru. Adapun untuk kuisioner NBM (Nordic Body Map) adalah metode untuk menganalisis keluhan-keluhan yang dihadapi mahasiswa pada bagian tubuhnya setelah perkuliahan. Pengambilan data dilakukan terhadap mahasiswa di Institut Teknologi dan Sains Nahdlatul Ulama Pekalongan. Diharapkan dari hasil penelitian ini, dapat menjadi metode pertimbangan didalam memperbaiki dan meningkatkan kualitas perkuliahan selama masa pandemic Covid19.

\section{Metode Penelitian}

Penelitian ini bertujuan untuk melakukan identifikasi terhadap mahasiswa selama melakukan perkuliahan daring pada masa pandemic Covid19. Pengambilan data dilakukan terhadap 30 mahasiswa mahasiswa di Institut Teknologi dan Sains Nahdlatul Ulama Pekalongan. Pengambilan data sampel dilakukan secara random sederhana (Arminas, 2016; Wajdi et al., 2020). Kriteria sampel pada saat pengambilan data adalah:Mahasiswa dari berbagai jurusan dan angkatan di Institut Teknologi dan Sains Nahdlatul Ulama Pekalongan, Mengikuti perkuliahan daring minimal 3 bulan atau 7 kali pertemuan kuliah, Mengikuti minimal 3 mata kulih, dan Sehat fisik dan psikis. Sampel yang diambil dan digunakan sebagai data analisis pada penelitian ini adalah yang memenuhi semua kriteria penelitian. Adapun prosedur penelitian mengikuti alur sebagai berikut:

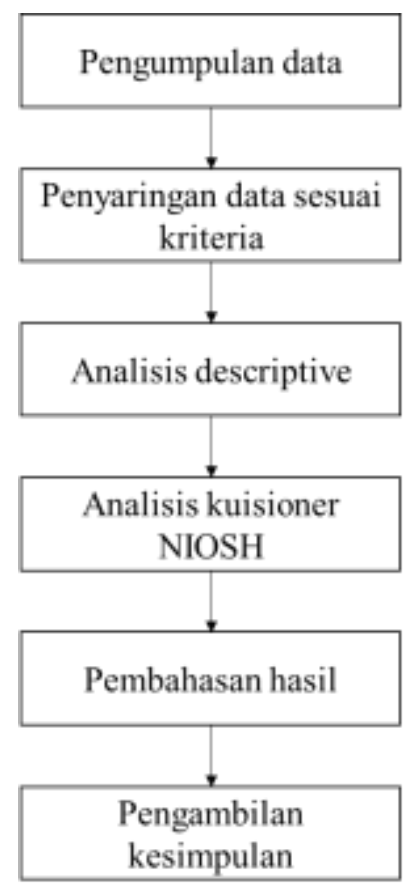

Gambar 1. Alur Penelitian

Proses diawali dengan pengumpulan data sebanyak 30 sampel. Pada pelaksanaannya digunakan aplikasi Google Form untuk mengisi konten yang tertera. Hal ini dikarenakan peraturan pemerintah yang tidak memperbolehkannya perkumpulan dalam satu tempat dalam waktu lama, sehingga segala kegiatannya dilakukan secara daring. Setelah data sampel diperoleh, selanjutnya proses dilanjutkan dengan penyaringan data yang sesuai dengan krtieria penelitian. Penyaringan ini akan berdampak pada kemungkinan data dari 30 sampel tersebut berkurang. Pada proses validasi, sampel yang tidak sesuai akan dihapus dan diambil kembali. Proses dilanjutkan dengan menganalisis analisis deskriptive menggunakan perhitungan statistik. Pada proses ini variabel yang dianalisis adalah umur, jenis kelamin, sarana dan prasarana untuk kuliah daring. Selain itu, pada form tersebut, terdapat juga kuisioner NBM (Nordic Body Map) yang bisa diunduh dan mengirim ulang hasil oleh mahasiswa. Berdasarkan hasil dari kedua analisis ini, maka akan dapat dilakukan pembahasan secara mendalam terkait keluhan, permasalahan, dan perbaikan yang dibutuhkan terhadap kegiatan perkuliahan yang 
telah dilakukan. Hasil ini selanjutnya dibutuhkan untuk mengevaluasi dan mengambil kesimpulan, serta saran yang dapat diberikan sehingga dapat menghindari kemungkinan terjadinya permasalahan yang lebih tinggi.

\section{Hasil dan Pembahasan}

\subsection{Analisis Deskriptive}

Pengambilan data dilakukan terhadap 30 sampel mahasiswa secara random sederhana, dengan proses melakukan pengisian Google Form tentang Keluhan Mahasiswa pada saat kuliah daring selama masa pandemic Covid19. Proses ini dilakukan selama 1 minggu. Berdasarkan hasil tersebut, dari 30 mahasiswa, hanya 26 sampel yang memenuhi kriteria. Sampel yang tidak memenuhi kriteria dikarenkan terdapat mahasiswa yang belum menempuh minimal 7 kali pertemuan, dan mengikuti kurang dari 2 mata kuliah. Distribusi mahasiswa yang mengisi form terdiri dari:

a. Persentase mahasiswa adalah $46 \%$, dan mahasiswi adalah 54\%. Dari informasi yang tertera diatas menunjukkan bahwa, tingkat antusiasme perkuliahan daring lebih didominasi oleh mahasiswi.

b. Sebanyak $77 \%$ merupakan yang berusia dibawah atau sama dengan 20 tahun, yang berarti mahasiswa angkatan baru dan mahasiswa mengulang. Sebanyal 23\% merupakan yang berusia antara 20 hingga 24 tahun tahun, yang berarti mahasiswa angkatan menengah hingga akhir. persentase angkatan menunjukkan bahwa perkuliahan yang dihadapi oleh mahasiswa angkatan baru lebih padat dibandingkan dengan angkatan lama.

Postur tubuh pada saat bekerja menjadi faktor utama yang menetukan tingkat keluhan yang dihadapi oleh manusia (Yang \& Cheung, 2016; Widanarko et al., 2016; Plantard et al., 2017). Postur tubuh yang kurang baik didalam bekerja akan berdampak pada resiko sakit pada bagian-bagian tubuh tertentu (Widyanti, 2018; Heidari et al., 2019). Sakit tersebut dapat dirasakan dalam waktu sementara hingga jangka panjang (Esmaeilzadeh $e t$ al., 2014; Li \& Xu, 2019). Penempatan alat juga memiliki pengaruh yang cukup besar terhadap postur tubuh. Pada penelitian ini beberapa variabel kuisioner yang terdapat pada Google Form, menanyakan terkait postur serta alat yang digunakan pada saat melakukan kegiatan perkulihan. Adapun hasilnya adalah sebagai berikut:

a. Persentase postur tubuh mahasiswa pada saat perkuliahan daring adalah $73.1 \%$ dengan duduk lesehan menggunakan meja tanpa kursi, $50 \%$ dengan tidur atau berbaring, 46.2\% dengan duduk menggunakan kursi dan meja, dan 3.8\% dengan berdiri. Postur duduk yang baik adalah menggunakan meja yang berfungsi untuk dapat menghindari postur leher menunduk dan punggung membungkuk secara ekstrim, sedangkan kursi berfungsi untuk menopang batang tubuh dan media bersandar untuk relaksasi tubuh. Dari informasi yang diperoleh pada hasil ini menunjukkan masih banyak mahasiswa yang melakukan kuliah online dengan postur yang buruk seperti tidak menggunakan kursi, tidur atau berbaring beresiko pada kesehatan mata, dan postur berdiri beresiko mengalami kelelahan yang lebih cepat dibandingkan dengan postur duduk (Mulyati et al., 2017; Purnomo \& Kurnia, 2018).

b. Perangkat kerja mahasiswa pada saat kuliah daring adalah terdiri dari $92 \%$ menggunakan Smarthphone, 76\% menggunakan Laptop, 4\% menggunakan Komputer, dan 4\% menggunakan Tablet. Penggunanaan perangkat kerja dengan resolusi layar kecil seperti smartphone sangat tidak disarankan pada saat melakukan kuliah daring. Hal ini berdampak pada kelelahan mata lebih cepat dibandingkan dengan perangkat dengan resolusi layar yang lebih besar seperti komputer, dan laptop. Penggunaan perangkat dapat juga disesuaikan dengan lamanya durasi pada saat perkulihan, dimana perkuliahan yang durasinya pendek akan lebih efektif menggunakan smarthphone. Oleh karena itu, penyesuian dapat dilakukan berdasarkan durasi perkuliahan yang hal ini dapat didiskusikan dengan pengampu perkuliahan.

\subsection{Analisis NBM (Nordic Body Map)}

Analisis NBM adalah metode yang digunakan didalam mengukur tingkat keluhan musculoskeletal disorders (MSDs) berdasarkan 27 titik tubuh manusia. Pengisian dilakukan dengan memberikan kuisioner yang berisi tabel NBM kepada subjek atau sampel penelitian, untuk diisi berdasarkan tujuan penelitian dan keluhan yang dimiliki pada tubuhnya. Analisis ini berfungsi didalam mendukung informasi yang diperoleh pada análisis deskriptive yang sebelumnya telah dilakukan. Tingkat keluhan pada penelitian ini terdiri dari 4 tingkatan yaitu: Tingkat 1 adalah mahasiswa tidak merasakan sakit; Tingkat 2 adalah mahasiswa merasa sakit namun hanya sebentar atau hanya pada hari kegiatan perkuliahan dilakukan; Tingkat 3 adalah subjek merasa sakit dalam jangka panjang atau lebih dari satu hari; dan Tingkat 4 adalah subjek merasa sakit yang permanen. Hasil NBM berdasarkan titik tubuh dengan persentase tertinggi terhadap tingkat sakit dapat dilihat pada Gambar 2. 


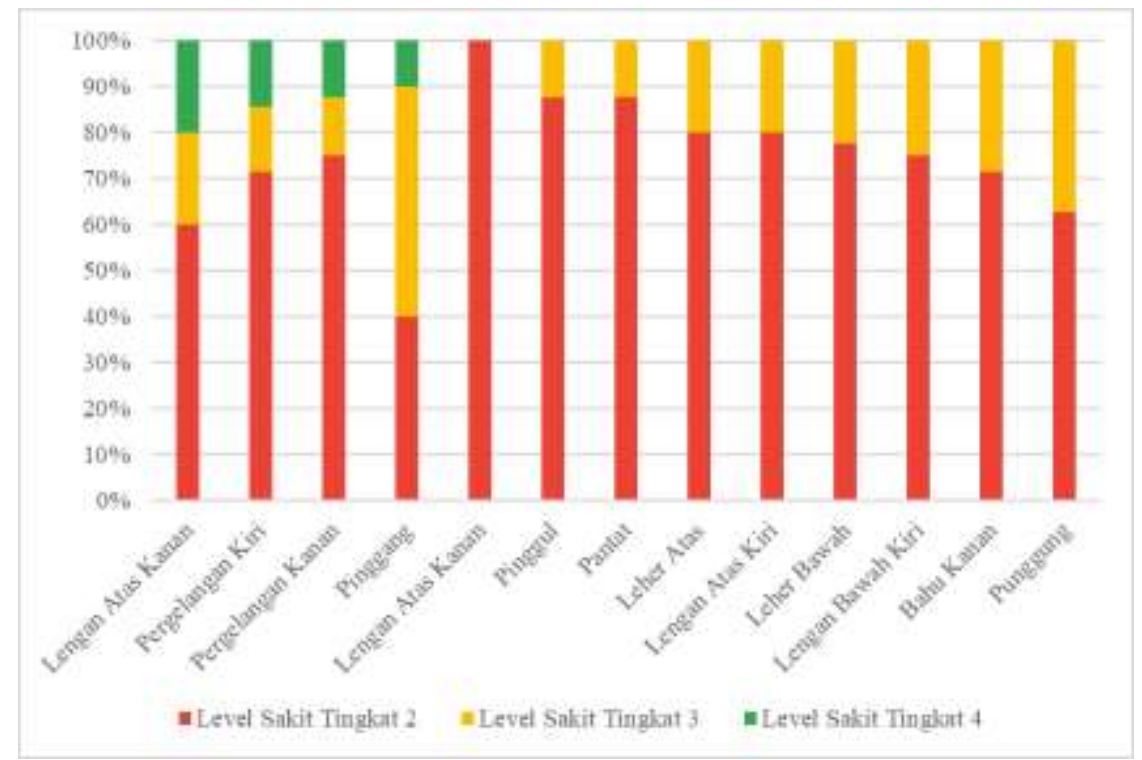

Gambar 2. Persentasi tingkat sakit pada titik tubuh mahasiswa

Pada Gambar 2., dapat dilihat bahwa titik tubuh yang paling banyak merasa sakit secara umum terletak pada area tangan (Bahu, lengan atas, lengan bawah, dan pergelangan), dan batang tubuh (leher, punggung, pinggul, pinggang dan pantat). Berdasarkan hal ini, dapat dievaluasi bahwa:

a. Rasa sakit pada area tangan disebabkan oleh kegiatan yang berhubungan dengan kegiatan menulis. Oleh karena itu, disarankan untuk dapat memberikan waktu pada mahasiswa untuk relaksasi dan meminimalisir kegiatan perkuliahan yang berikaitan dengan menulis. Jika dihubungkan dengan postur dan perangkat kerja yang digunakan (Sub-bab 3.1), keluhan dapat disebakan oleh perangkat kerja yang kurang tepat (Dianat et al., 2020; Rosaria et al., 2020). Misalnya perangkat yang digunakan hanya smarthphone dan alat tulis manual dapat menyebabkan kelelahan pada saat menulis di meja kerja, hal ini juga dapat berdampak pada berkurangnya konsentrasi. Solusi yang dapat meminimalisir adalah penggunaan laptop atau komputer, yang memungkinkan mahasiswa menulis hasil perkuliahan langsung di perangkat tersebut.

b. Rasa sakit pada batang tubuh, disebabkan oleh bagian ini merupakan penyangga seluruh tubuh manusia (Rosaria et al., 2020; Candan et al., 2019). Pada bagian ini, tekanan akan sangat terasa jika verada pada postur duduk sehingga dibutuhkan media pendukung untuk menguranginya. Jika dihubungkan dengan postur dan perangkat kerja yang digunakan (Sub-bab 3.1), keluhan timbul akibat postur tubuh pada saat perkuliahan yang baik seperti hanya menggunakan meja tanpa kursi, menggunakan perangkat smarthphone sambil tidur atau berbaring, penggunaan smarthphone dengan durasi perkuliahan yang lama. Solusi untuk dapat meminimalisir permasalaha ini adalah penggunaan meja dan kursi yang ergonomis, dan penggunaan perangkat kerja yang tepat (Arminas, 2016; Purnomo \& Kurnia, 2018).

\section{Simpulan}

Sejak adanya pandemic Covid19, terjadi perombakan secara menyeluruh pada semua sector industri tentang cara yang efektif agar kegiatan usaha tetap berjalan. Masalah ini juga berdampak pada sector pendidikan. Perguruan Tinggi dari berbagai daerah di Indonesia, berusaha semaksimal mungkin agar kegiatan perkuliahan tetap berjalan. Salah satu caranya adalah dengan melakukan perkuliahan daring. Mahasiswa merupakan faktor utama yang menentukan kegiatan perkuliahan berjalan dengan benar. Proses belajar yang lama menjadikan mahasiswa mengalami banyak keluahan mulai dari stress kerja, bagian tubuh tertentu sakit, tidak focus, dll. Oleh karena itu, dilakukan penelitian tentang identifikasi keluhan kesehatan pada mahasiswa selama kuliah daring pada masa Covid19. Metode penelitian menggunakan analisis desktiptive dan penyebaran kuisioner NBM (Nordic Body Map), terhadap 30 mahasiswa di Institut Teknologi dan Sains Nahdlatul Ulama Pekalongan.

Hasil menunjukkan bahwa persentase postur tubuh mahasiswa pada saat perkuliahan daring adalah $73.1 \%$ dengan duduk lesehan menggunakan meja tanpa kursi, $50 \%$ dengan tidur atau berbaring, $46.2 \%$ dengan duduk menggunakan kursi dan meja, dan 3.8\% dengan berdiri. Postur yang kurang baik pada saat perkuliahan mendominasi persentase. Perangkat kerja mahasiswa pada saat kuliah daring adalah terdiri dari 92\% menggunakan Smarthphone, 76\% menggunakan Laptop, 4\% menggunakan Komputer, dan 4\% menggunakan 
Tablet. Perangkat kerja harus disesuaikan dengan kebutuhan sehingga dapat menghindari resiko buruk yang mungkin terjadi.

Saran yang dapat diberikan dari hasil penelitian ini adalah dibutuhkannya kerjasama yang baik antara mahasiswa dan pengampu perkuliahan tentang kenyamanan dalam proses belajar-mengajar, penggunaan perangkat kerja yang sesuai sehingga terhindar dari resiko keluhan sakit pada tubuh, dan penggunaan media pendukung sebagai perantara antara mahasiswa dengan perangkat kerjanya.

\section{Daftar Pustaka}

Adams, R. J., Lichter, M. D., Krepkovich, E. T., Ellington, A., White, M., Diamond, P. T. 2015. Assessing Upper Extremity Motor Function in Practice of Virtual Activities of Daily Living. IEEE Transactions on Neural Systems and Rehabilitation Engineering, Vol. 23, No. 2, pp. 287-296.

Arminas. (2016). Perancangan Fasilitas Kerja dan Perbaikan Postur Kerja pada Aktivitas Manual Material Handling Karyawan Toko Mega Mas Elektronik Makassar. Jurnal Ergonomi dan K3, Vol.1, No.1.

Candan, S.A., Sahin, U.K., Akoğlu, S. 2019. The investigation of work-related musculoskeletal disorders among female workers in a hazelnut factory: Prevalence, working posture, work-related and psychosocial factors. International Journal of Industrial Ergonomics, Vol. 74, Doi: https://doi.org/10.1016/j.ergon.2019.102838.

Dianat, I., Afshari, D., Sarmasti, N., Sangdeh, M.S., Azaddel, R. 2020. Work posture, working conditions and musculoskeletal outcomes in agricultural workers. International Journal of Industrial Ergonomics, Vol. 77, Doi: https://doi.org/10.1016/j.ergon.2020.102941.

Esmaeilzadeh, S., Ozcan, E., Capan, N. 2014. Effects of ergonomic intervention on work-related upper extremity musculoskeletal disorders among computer workers: A randomized controlled trial. Int Arch Occup Environ Health, Vol.87, pp. 73-83.

Heidari, H., Soltanzadeh, A., Asemabadi, E., Rahimifard, H., Mohammadbeigi, A. 2019. Ergonomic posture analysis of different postures in laptop users at non-official places and related musculoskeletal disorders by rapid upper limb assessment method. Adv Hum Biol, Vol.9, pp.135-142.

Kar, S.K., Arafat, S.M.Y, Sharma, P., Dixit, A., Marthoenis, Kabir, R. (2020). COVID-19 pandemic and addiction: Current problems and future concerns. Asian Journal of Psychiatry, Vol. 51.

Li, L., \& Xu, X. 2019. A deep learning-based RULA method for working posture assessment. Proceedings of the Human Factors and Ergonomics Society Annual Meeting, Vol. 63, No. 1, 1090-1094.

Manghisi, V. M., Uva, A. E., Fiorentino, M., Bevilacqua, V., Trotta, G. F., Monno, G. 2017. Real time RULA assessment using Kinect v2 sensor. Applied Ergonomics, Vol. 65, pp. 481-491.

Minghat, A.D., Ana, A., Purnawarman, P., Saripudin, S., Muktiarni, M., Dwiyanti, V., Mustakim. S.S. (2020). Students' Perceptions of the Twists and Turns of E-learning in the Midst of the Covid 19 Outbreak. Revista Romaneasca pentru Educatie Multidimensionala, Vol. 12, No.1, pp. 15-26.

Mulyati, D., Viena, V., Irhamni, Baharuddinsyah. (2017). Analisis Postur Kerja Manual Material Handling Dengan Metode Ovako Working Analisis System (OWAS) Pada Home Industri Mawar. Seminar Nasional Teknik Industri (SNTI2017), hal. 1-8.

Ng, A., Hayes, M., Polster, A. 2016. Musculoskeletal Disorders and Working Posture among Dental and Oral Health Students. Healthcare, Vol. 4, No. 1, Doi: https://doi.org/10.3390/healthcare4010013.

Plantard, P., Shum, H. P. H., Le Pierres, A. S., Multon, F. 2017. Validation of an ergonomic assessment method using Kinect data in real workplace conditions. Applied Ergonomics, Vol. 65, pp. 562-569.

Purnomo, H., Kurnia, F., Sobirin. M. 2018. Ergonomic Student Laptop Desk Design Using The TRIZ Method. 4th International Conference on Science and Technology (ICST), Hal. 1-4.

Rosaria, C., Alessandro, N., Chiara, C. 2020. Comfort seat design: Thermal sensitivity of human back and buttock. International Journal of Industrial Ergonomics, Vol. 78, Doi: https://doi.org/10.1016/j.ergon.2020.102961.

Sukmana M., Aminuddin, M., Nopriyanto, D. (2020). Indonesian Government Response In COVID-19 Disaster Prevention. East African Scholars Journal of Medical Sciences, Vol.3, No.3, pp. 81-86.

Wajdi, M.B.N., Kuswandi, I., Al Faruq, U., Zulhijra. (2020). Education Policy Overcome Coronavirus, A Study of Indonesians. EDUTEC Journal Of Education And Technology, Vol. 3, No.1, pp. 96-106. 
Widanarko, B., Leg, S., Devereux, J., Stevenson, M. 2016. Interaction between physical and psychosocial work risk factors for low back symptoms and its consequences amongst Indonesian coal mining workers. Applied Ergonomics, Vol. 46, pp. 158-167.

Widyanti, A. 2018. Ergonomics check point in agriculture, postural Analysis, and Prevalence of Work Musculoskeletal Symptoms among Indonesian Farmers: Road to Safety and Health in Agriculture. Jurnal Teknik Industri, Vol. 20, No.1, pp. 1 - 10.

Yang, Z., Cheung, T.W.C., 2016. The inclusion of homemakers as an occupation amongst people with upper limb repetitive stress injuries. Work, Vol. 55, pp. 181-186. 